Gillian Simpson*

ORCID: 0000-0003-4653-289X

York, Great Britain

\title{
In Community, Alone, in Community: Towards an Understanding of Christian Faith for the Post-Enlightenment, Post-Evangelical, Post-1960s Revolution Generation
}

\author{
We wspólnocie, samotnie, we wspólnocie: \\ ku rozumieniu chrześcijańskiej wiary przez \\ pokolenie postoświeceniowe, poewanglikalne, \\ i po rewolucji lat 60 .
}

\begin{abstract}
The Christian Creeds outline the central beliefs of Christianity, providing a universal statement of faith for Christians everywhere. This is an account of one perspective on the Creeds, which begins in a narrow Christian community, moves through isolation and solitude, and ends at the edges of a new community; a journey which edges towards the human goal of self-acceptance and understanding. The doctrines are often perceived as fact, but are there grounds for a more nuanced approach? Theologically, some insiders have developed new approaches to Christianity, while traditional Church theology maintains a stubborn outward attitude of non-compromise. Others who have attempted to develop a more existential
\end{abstract}

* Gillian Simpson, Senior Lecturer, School of Humanities, Religion \& Philosophy, York St John University, email: g.simpson@yorksj.ac.uk. 
approach have been often vilified and disowned by the Church. But is there a third way? One which encompasses neither theological technicality nor angry emotional rejection, but a gradual dawning, personal realisation that we are all moving from one type of community to another, and that the answers lie in doubt rather than certainty. This paper analyses internal and external dialogues the author has experienced, when moving from the confines of a small Evangelical Christian Church community, through solitude, to the tentative edges of a new multi-vocal community. Starting with an analysis of Fowler's methodology as a tool to evaluate the faith narrative, the author will examine the multiplicity of voices that have informed her journey. She will stop on the way to challenge and encourage the young adult who has become an outsider, to acknowledge the voices of dissenters, to accept a different form of spiritual friendship, and to encounter an evolving community which accepts new voices of gender, doubt and radical interpretation. Finally, she will visit a new creed and ask whether, in the famous words of T. S. Eliot, '.. the end of all our exploring / Will be to arrive where we started / And know the place for the first time'.

Keywords: Christian; faith-development; faith-modelling; community; isolation; dialogue; doubt.

Abstrakt: Chrześcijańskie Credo wylicza główne prawdy chrześcijańskiej wiary, zapewniając jej uniwersalne wyznawanie wszystkim chrześcijanom. W tekście przedstawiono stanowisko autorki, perspektywę ujmowania wiary narodzonej w wąskiej chrześcijańskiej wspólnocie, przeniesionej przez izolację i samotność na brzeg nowej wspólnoty, mającą za cel osobową samoakceptację i zrozumienie. Doktryny są zwykle postrzegane jako fakty; czy istnieje jednak miejsce na światłocienie, na bardziej zniuansowane interpretacje? W teologii niektórzy „wtajemniczeni” rozwijali nowatorskie podejścia do chrześcijaństwa, podczas gdy tradycyjna kościelna teologia pozostaje zewnętrznym, upartym stanowiskiem braku kompromisu. $\mathrm{Ci}$, którzy próbowali rozwijać bardziej egzystencjalne podejścia, byli często szkalowani i usuwani z Kościoła. Jednak czy istnieje trzecia droga? Taka, która zakłada nie teologiczny formalizm czy wściekły, emocjonalny bunt, ale stopniowe przebudzenie świadomości, że wszyscy wyrastamy z jednego typu wspólnoty ku innemu, a odpowiedzi leżą bardziej w wątpliwościach aniżeli w pewności. Artykuł analizuje wewnętrzne i zewnętrzne dialogi, które autorka prowadziła w okresie przechodzenia z granic małego Ewangelikalnego Kościoła, poprzez samotność, do niepewnych brzegów nowej, wielogłosowej wspólnoty. Rozpoczynając od analizy metodologii Fowlera, jako narzędzia ewaluacji religijnych narracji, autorka bada wielość głosów, które oddziaływały na jej wewnętrzną podróż. Przystanki na tej drodze wynikały z potrzeby: wsparcia i zachęty wobec młodych dorosłych „outsiderów”, umocnienia 
głosów „odszczepieńców”, akceptacji różnych form duchowej przyjaźni i wreszcie napotkania rozwijającej się wspólnoty, która zdolna jest pomieścić nowe głosy „gender”, wątpliwości i radykalne interpretacje. Ostatecznie przygląda się „A New Creed” i zastanawia się - słynnymi słowami T. S. Eliota - czy rzeczywiście „...pod koniec wszystkich naszych odkryć dotrzemy tam, skąd wyruszyliśmy i poznamy to miejsce po raz pierwszy".

Słowa kluczowe: chrześcijaństwo; rozwój wiary; modelowanie wiary; wątpliwości; izolacja; wspólnota; dialog.

\section{Introduction}

In my beginning is my end. In succession Houses rise and fall, crumble, are extended, Are removed, destroyed, restored, or in their place Is an open field, or a factory, or a by-pass.

T. S. Eliot, East Coker

T. S. Eliot observes that the end of life can be found in its beginning. Eliot's observations refer to a deep-rooted tradition in society, in which 'the same sort of people do the same thing in the same place from generation to generation' (Asher, 1995, p. 101). In that cyclical life was a communal certainty that allowed and protected individual incursions into aloneness. The greatest Christian mystics, whose work stemmed from solitude, were nurtured by church communities that sustained and protected them. They lived lives of solitude, which Eliot had been drawn to around the time of his conversion in 1925 (Gordon, 2012). In this circle of life, the exploration of faith beyond safe doctrinal boundaries was either regulated by the Church in monastic communities, or was branded heretical. Is this still the case today? I argue that it is not. This article follows one 'Christian' journey, from a doctrinally bounded community, through wading in 'heretical' waters, to acceptance of a different kind of understanding - one that involves inter-religious permeable membranes (perhaps considered heretical by some quarters of the establishment), which allow the interfusion of dangerous 'heretics' with established doctrines.

I argue that Christian faith for Post-Evangelicals, from the post-1960s Cultural Revolution and beyond, need not be dismissed as irrelevant. By fusing traditional approaches to belief with those dangerous alternatives, we can create a space which provides room for dialogue between traditionalists and 
'heretics'. This paper is not a challenge to traditional doctrine, nor do I intend to stereotype different forms of Christian belief by polarising traditionalists against a post-modern consciousness (however that is defined). Rather, it is a common shore where people of different approaches can paddle in the shallows together, towards a new understanding based in dialogue.

As Walter Brueggemann observes, we live in a world in which the 'old-imagined' Christian world has vanished, and the new one provides no clear path for a new imagination. For Brueggemann, the task of the church is to 'provide materials and resources' from which people can piece together new configurations of faith. The point at which liturgy and proclamation meet is '... a place where people come to receive new materials, or old materials freshly voiced, that will fund, feed, nurture, nourish, legitimate and authorise a counterimagination of the world' (Brueggemann, 1993, p. 20). Since then, there have undoubtedly been Church-led initiatives which seek to bridge the divide between faith and doubt, though writers who have challenged mainstream approaches from outside the Church are still often vilified. There is still a long way to go.

To address the gap between literal faith and one which questions and challenges the literalist approach, I invite James Fowler into the shallows. A pioneering work of the 1970s, Stages of Faith draws on the work of developmental psychologists ${ }^{1}$ and a number of recent theologians; among them H. Richard Niebuhr, who observed that faith requires loyalty to common 'centers of value and causes', and that human searches for 'truth' are likely to be seen as meaningless if not centrally grounded. This common centre is understood as 'gods, not as supernatural beings but as value-centers and objects of devotion' (Niebuhr, 1960, pp. 22-23). For Fowler, faith is a means of learning about and making sense of life through engagement with those value-centres and objects of devotion. He approaches faith as a verb, a dynamic system of images, values and commitments that guides individuals through life. John McDargh (2001, p. 186) notes: 'Fowler is concerned to render an account of faith as a human universal, a kind of talent or potentiality given with human nature', suggesting the possibility of bridging the gap between undifferentiated belief in God and belief which is grounded in reflective doubt. Notwithstanding the critiques, ${ }^{2}$ Fowler justifies his model of faith in relation to increasing secularisation that threatens the stability

\footnotetext{
${ }^{1}$ Notably Piaget, Erikson and Kohlberg.

${ }^{2}$ Fowler addresses some of the concerns in: Stages of Faith From Infancy Through Adolescence: Reflections on Three Decades of Faith Development Theory (2006, p. 43 ff.).
} 
of religious and moral authority on the one hand, and the growth of both fundamentalist and conservative practices and 'non-religious' approaches to spirituality on the other (Fowler \& Dell, 2006, p. 44). This indicates the need for new religious spaces based in shared values and commitments. I hope we can unite both approaches, and reconcile the beginnings in literal belief with a more nuanced, 'adult' approach, which will '[at] the end of all our exploring' return us to the space where we started, and know it for the first time (Eliot, 1963, p. 222).

This article uses two narratives: the author's own faith development narrative (written in italics), and reflections on that narrative; these aim to establish common connections with other readers' own narratives.

\section{A personal narrative explored}

This is the author's story; she was born with a Christian blueprint, reinforced in a Creed. She embraced, then questioned, despised, rejected, and eventually reappraised these beliefs in perhaps heretical yet liberating ways. Born into an Anglican family, she grew up in the 1960s and 70s, a time of liberation and changing values in society. ${ }^{3}$ Sheltered from the harmful effects of 'antiscriptural' approaches which could threaten the foundations of Christian society, she grew into a world which was increasingly rejecting Christian norms, and found she was becoming alienated from the Church, society and herself. As she became a young adult, with all the trappings - falling in love, marriage and family; the Christian ideal - her life was outwardly connected, communal, and relational. Eventually there was a moment of crisis which led her out of that world into a profound sense of alienation; but gradually, through chance encounters, she learned new pluralistic forms of understanding, and found herself 'Arriv[ing] where she started / And know [ing] the place for the first time' (Eliot, 1963, p. 222). There is nothing remarkable in her story - it is a common story of human development from birth into a faith community, to aloneness, and back to the edges of a new counter-imagined Christian community, based in a 'doubtful faith' which enabled old creeds to take on new meanings.

3 The 1960s baby boom, flower power, and feminist, black and gay rights movements all contributed to the dawning of a new era of acceptance and the breaking down of White Western norms. 
The process of 'becoming' meant reappraising my literal childhood faith; this was facilitated by an encounter with Fowler's work. Originally published in $1976,{ }^{4}$ this text has become a modern classic that offers a new perspective on belief. Here at last was something that put flesh on the bones of a faith being prepared for burial; Fowler made sense. Yes, it was pseudo-scientific; nevertheless it defined what half a generation of Church teaching had failed to do: the ideas worked. It answered the unverbalised questions about belief, and treated them not as failure, but as part of a process of human development.

Fowler (1995, p. xiii) builds on educational and moral development theories $^{5}$ to develop a new approach to faith that enables us to 'grasp, clarify and work effectively with the most vital processes of our lives', while taking the theory with 'a serious playfulness and a playful seriousness' (Erikson quoted in Fowler, 1995, p. xiii). He identifies five stages which roughly equate to educational, moral and physical development, recognising discernible patterns that move beyond conventional symbols of faith and belonging, into self-examination and encounter with the other, community and self.

Fowler's concept of self, however, fails to address gender perspectives. Nicola Slee (2003) notes the importance of feminine voices in faith development; this is particularly salient to my own discussion, writing as a woman who grew up in a patriarchal Christian community. ${ }^{6}$ Nevertheless, his model remains a useful instrument for evaluating the challenge of faith maturation within institutional churches. This is further underpinned by Adrian Coyle (2011, p. 21-22), who observes that despite the notable shortcomings of Fowler, particularly in relation to the 'invariant, sequential and hierarchical nature' of his model,

In a Western culture in which religious faith is increasingly appraised negatively, such an understanding constructs religious faith not as a bizarre phenomenon but as arising from and being an expression of a universal human meaning-making orientation. It also allows the conceptualisation of faith development to draw upon 22 theories from the psychological mainstream, reducing the risk of its ghettoisation.

${ }^{4}$ Re-published in 1995.

5 Notably the works of Piaget, Erikson and Kohlberg.

${ }^{6}$ Fowler himself acknowledges this in his subsequent research: Faith Development at 30: Naming the challenges of faith in a new millennium (2004). 
This journey starts with the early sense of trust transmitted by my parents, which enabled the development of nurturing and sustaining healthy relationships in family, church and school (Erikson, 1980). There was what Fowler identifies as 'the inevitable anxiety and mistrust that result from the ... emotional experiences of separation and self-differentiation which occur during infant development' (Fowler \& Dell, 2006). However, when I grew up in a faith environment, these bonds of attachment reinforced Christian mutuality and helped develop a sense of personhood, as both a separate entity and as a member of a bounded community. The world was viewed through a glass clearly, within a structured and evangelically framed God-consciousness. Concepts of 'good' and 'bad' were also enclosed within the same Godshaped boundaries (with very little differentiation between the ultimate authority of God and of parents), thus giving parameters for living and believing, which controlled both reward and punishment. Belief was the stuff of myth and legend, 'appropriated with literal interpretations' (Fowler, 1995, p. 149). Moral rules and attitudes were similarly literally shaped, with the Bible as the backbone of understanding, in which the fantastic and the mundane fused together seamlessly as fact. Parental authority was a safe space within which a growing sense of separation and self-differentiation was subjugated (Fowler \& Dell, 2006, p. 36). Hence belief in God the Father Almighty equated to belief in the patriarchal family structure.

Fowler (1995, p. 173) emphasises the dangers of these constraints, noting that without careful nurturing, literalness can result in the construction of an environment constricted by the need for stilted perfectionism - a comment which post-Evangelicals may well embrace. As a young adult, discussions about faith with my father (whose religion was built on systems and structures of belonging) brought about my first conscious encounter with doubt, shaking the foundations of literal belief. His authoritative persona had previously helped build a world of stability and trust, yet it had belied his doubt and uncertainty. Gradually the literalness which had formed the child's narrative was exposed as a myth. Seeing below the surface of another person brings us face to face with the realisation that we are not what we believe ourselves to be; that 'even after a deeper level ... appeared ... below a vanishing surface ... that deeper level itself becomes a surface' (Tillich, 1949, p. 63). His questions about the nature and existence of God, and the inadequacy of Church structures to help him in his faith crisis, caused shock waves as I realised that he was 'not waving but drowning' (Smith, 1957), alone in a sea of institutionalism and literalness. 


\section{Alone in the Church}

The words of the Creed sounded the warning: 'I believe in Jesus Christ ... who was conceived by the Holy Ghost, born of the Virgin Mary'. At the end of this arose a question mark. 'Do I really believe that?'And the more she questioned, the more the answer came back a resounding 'NO'. Now struggling to maintain a sense of collective and personal identity in her religious community, the author has rejected the 'mythic-literal' roots of her childhood. She needs to conform to gain peer acceptance, yet she cannot, driven by a sense of profound dissonance. But she cannot break free; her 'self' is far from being fully formed. There is conflict between her communal and personal identities, and the evangelical community is unable to accommodate her growing sense of anxiety and doubt. The messages she receives from authority figures further alienate her from developing a more differentiated approach to faith; she reaches a point where she can no longer hold together the conflicting demands of communal and personal identities. Her communal identity is in shreds, her personal identity is not yet strong enough to sustain her; doubt forms her internal dialogue while the outward appearance of faith is maintained in her communal identity; there is a deepening sense of isolation and incongruence.

Questioning literal belief can isolate people from the communities that nurtured their early development. After the conformity of infancy and youth, in which community, identity and belief are sustained by significant authority sources, an encounter with doubt can lead to either a physical or emotional 'leaving home'. As Fowler (1995, p. 173) notes, as a young adult ${ }^{7}$ encounters the breakdown of trust in familiar patterns, symbols and norms, this 'precipitates the kind of examination of self, background, and life-guiding values that gives rise to transition at this point'. 'Leaving home' is accompanied by the conflict between intimacy and isolation which occurs during this time (Gold \& Rogers, 1995, pp. 79-85). The need for committed, emotionally fulfilling relationships can leave the sense of self scarred by an inability to continue social relationships in a religious community which no longer accommodates the emerging self; thus, communal and personal identities become conflicted.

${ }^{7}$ Fowler notes that the challenge to synthetic-conventional (stage 3) faith typically happens in young adults, but can happen in the late thirties or forties. 
Alan Jamieson (2002, p. 62) identifies this process of isolation and leaving the $\mathrm{EPC}^{8}$ church as a normal part of the changing nature of faith. He uses the term 'Reflective Exiles' (REs) to describe people who undergo a fundamental shift of consciousness through questioning their core beliefs and values; he identifies a common pattern which begins with 'meta-grumbles':

They are not grumbling about specifics within the church but about the function, role and place of church itself. Grumbles about what it means to be a Christian. How much are we left to do our own thing in life? What is prayer? How do we understand and use the Bible? Even, who is Jesus? And for some Does God exist? ... Meta-grumbles question the deep-rooted foundations of the faith itself. For these people it is the core of their faith that is being shaken in the process. (ibidem, p. 61)

This process culminates in a new sense of self:

In the process of deconstructing and reflecting on their faith, many of the Reflective Exiles develop a new trust for their emotions and intuitions, which they use as part of the judgement they bring to each segment of the faith they are evaluating. Although for most the weighing of their faith involves thoughtfulness and the search for new understanding, many also mentioned a renewed trust in their own emotions and intuitions. (ibidem, p. 71)

Jamieson also highlights the resulting loss of identity, confidence and self-esteem in leaving an EPC community. His work, like Fowler's, provides a liminal safe-space for REs to recognise that, although 're-examination can be a deeply painful process' (Fowler \& Dell, 2006, p. 41), it is part of the process of maturation.

One solution for Jamieson $(2009$, p. 222) comes in the form of "postchurch' groups; ${ }^{9}$ these are fluid organisations which exist solely for the ben-

${ }^{8}$ Evangelical, Pentecostal and Charismatic.

9 Jamieson notes a common feature of post-church groups: 'they were formed to provide a forum for people to discuss topics and issues that were "out-of-court" in the EPC church environments they had left. They are places where doubts about faith, anger and disappointment with the church (or with God) can be expressed, and where questions can be raised which address the foundational core of the theology, practice, beliefs and worldview of the EPC churches ... Safe places are places where there is no censorship of feelings, intuitions, doubts and ideas.' (Jamieson, 2009, p. 222) 
efit of their members, providing a place where there is 'no censorship of feelings, intuitions, doubts and ideas', and which can continue to nurture faith identities. That is all very well for REs who maintain an allegiance to Church, but for some the trauma of leaving imparts a potentially lasting legacy of anger and antipathy. Post-church groups fail to address disaffected, unaffiliated church-leavers who nevertheless wish to maintain a tenuous grasp on Christianity in a post-Christian society; there is no safe space for their doubt. So what role is there for REs who abandon organised religion and yet cannot quite shake it off?

Richard Holloway (2001, p. 185) observes that conservatives in the Christian tradition are:

People who find themselves in these guardian roles often have a high practical intelligence, but they are rarely reflective or open to doubt; there may even be a strong genetic predisposition in them to the unquestioning acceptance of system and order... Further down the chain of authority from these strong types we find the ... rather shallow beneficiaries of the prevailing system who have done little to protect or extend it, but they offer it the homage of their uncomprehending benediction... The strong types end up as fundamentalists who can only 'defend tradition in the traditional way'.

These are harsh words that reflect the danger of stagnation in traditions which Holloway believes can only be truly mitigated by reflective doubters: 'the very people who are persecuted by the system for their heresy and corruption may be the agents that preserve whatever is enduringly sound in the tradition in question' (ibidem). He uncompromisingly seeks a space for those who have lost the support of their religious communities, and while he acknowledges that it is fundamentally important to educate the young by 'their inculturation into the tradition of the community in which they belong', there must also be a radical second part to the process, to deconstruct the tradition that has initially been internalised (ibidem, p. 186). They "need subversives who have mastered the tradition so thoroughly that they know instinctively that it must constantly be undermined if it is to have any hope of enduring' (ibidem, p. 187), and a new community which instils 'emotional confidence that will enable them to adapt to the changes their lives will encounter', rather than a traditional community that ' $\operatorname{arm}[\mathrm{s}]$ them with fixed and solid certainties that are likely to collapse under the pressure of events' (2004, p. 192). They need a safe space for rebellion which affords vital breathing space in which to mature and grow. To avoid the nihilistic despair of which Fowler (1995, 
p. 173) writes, upon the loss of conformist faith, Holloway invites his reader to abandon defensiveness and fear, and to live honestly, 'dancing on the edge' and 'not being afraid' (1997, p. 200), by allowing the 'edge' to become a permanent home. It is about allowing ourselves to be at the edge, rather than being impelled - either by intellectual struggles with 'doctrinal elements of the Church', or the 'moral disapproval of prominent Christians because of the way we live or the kind of people we are', or because of the mistakes we have made (1997, p. xi). Holloway has been variously called prophetic, controversial, a compassionate critic, a barmy bishop; but his nuanced approach to faith and doubt opens up a safe place for REs to explore.

\section{Alone in the Wilderness?}

When the forms of an old culture are dying, the new culture is created by a few people who are not afraid to be insecure. (Rudolph Baro)

The decision to leave the Church is not easy, but membership of a group in which the author now feels an outsider is increasingly unsustainable. The confines of the community are no longer tenable, and in seeking to find meaning, the myth of the Christian narrative implodes. She is aware that her conflict and doubt can find no resolution within this community and knows she must leave; leaving is painful, but staying is impossible. There is deep sadness, loneliness and alienation, but it is mitigated by the exploration of 'the edge', which begins to open up new horizons and perspectives on faith. She is able to ask difficult questions of new mentors who propose alternatives, none of which she had encountered in her faith community; all these mentors are pushing boundaries while remaining profoundly Christian.

In our search for meaning, "we look out on life and in on ourselves, and that act gives rise to religion, which is a way of connecting ourselves to the mystery of what is beyond ourselves' (Holloway, 2001, p. 54); and letting go of organised religion is part of that search. The breakdown of early 'authority sources' and the process of 'leaving home' (emotionally or physically), while painful, opens up space for deeper examination 'of self, background and life-grounding values' (Fowler, 1995, p. 173). This 'aloneness' requires the presence of significant mentors to help configure a more nuanced faith. 
It is clear for today's exiles that there needs to be a safe 'religious' space in which to counter-imagine life beyond the boundaries of organised religion. For Brueggemann (1993, p. 20) the task is:

... to fund - to provide the pieces, materials and resources out of which a new world can be imagined. Our responsibility, then, is not a grand scheme or a coherent system, but the voicing of a lot of little pieces out of which people can put life together in fresh configurations ... the work of funding consists not in the offer of a large, ordered coherence, but in making available lots of disordered pieces that admit of more than one large ordering.

If organised religion (including the post-EPC Church) cannot do this for REs, then we need new mentors who can offer those fragments, materials and resources with which to piece together a new form of religious consciousness.

One such mentor was Thomas Merton, a Trappist monk and civil rights activist who exemplified Fowler's description of 'universalising faith'. Merton creates and sustains 'zones of liberation' which invite us to partake in 'visions of universal community [which] penetrate [the] obsession with survival [and] security' of so many religious institutions. He discloses what Fowler (1995, p. 200) calls 'the partialness of our tribes and pseudo-species', and creates universal themes of love, care and compassion which transcend the partiality of institutionalism. For the RE who no longer sees any good in the institutional Church, it is tempting to harbour resentment for the structures that upheld their early community. But for Merton (1961, p. 56), that hatred belies a lack of sense of self:

There is in all weak, lost, and isolated members of the human race an agony of hatred born of their own helplessness, their own isolation. Hatred is the sign and the expression of loneliness, of unworthiness, of insufficiency. And in so far as we all are lonely, are unworthy, we all hate ourselves. Some of us are aware of this self-hatred, and because of it we reproach ourselves and punish ourselves needlessly. Others who are less conscious of their own self-hatred ... project it onto others.

For Merton (ibidem, p. 61), recovery of the self comes through solitude and contemplation, not by 'travelling but by standing still'. It was the integrity born of contemplation with which he wrote, that led the Dalai Lama to reflect that Merton's spirituality was embodied in his person, and that what Merton said and wrote was in fact who he was (Bochen, 2000, p. 21); furthermore, 
his fusion of interior and exterior worlds extends a hand to REs whose identities have become fragmented and lost. If one is used to a life of religious routine and structure grounded in superficial certainty, breaking free requires wading into deeper waters. Merton's writing provides just such a framework of solitude and silence. He acknowledges the 'importance of freedom from the routines and illusions which keep us subject to things [whether material or spiritual], dependent on what is outside us' (Merton, 1994, pp. 329-30); a freedom which gives rise to creative and redemptive power (Merton, 1985, p. 159). He offers an alternative community in which the illusory self, the 'false self' with which we have lived and grown, is recognised as being outside of reality and outside of life (Merton, 1961, p. 33). He invites us to take part in a new story, which begins in and tests us with a wilderness 'full of uncertainty and peril and humiliation and fear', in order to enter the dark night and move on to a new form of living. This is a living which Fowler (1995, p. 182) notes is grounded in the self's awareness of its 'own boundaries and inner-connections' rather than the communal restraints of the previous community; it is a place where the myths can be demythologised and translated into concepts consistent with a growing awareness of our deepening maturity.

Merton (1961, pp. 92-93) provides a different freedom for the RE to restructure the Creedal formulae:

If instead of resting in God by faith, we rest simply in the proposition or the formula [of the Creed], it is small wonder that faith does not lead to contemplation. On the contrary, it leads to anxious hair-splitting arguments, to controversy, to perplexity, and ultimately to hatred and division... The importance of the formulas is not that they are ends in themselves, but that they are means through which God communicates his truth to us ... we must not be so obsessed with verbal correctness that we never go beyond the words to the ineffable reality which they attempt to convey... Faith, then, is not just the grim determination to cling to a certain form of words, no matter what may happen ... [it] is the opening of an inward eye, the eye of the heart, to be filled with the presence of divine light.

Nevertheless, it has to be acknowledged that for most people a life of solitary contemplation is problematical, and that Merton's writings are born of the privileged hegemonic model of the Western white, solitary male. From the author's particular gendered perspective, as a woman brought up in an EPC environment, and standing in the ruins of a post-EPC world, this life is seen as ideal but unattainable. Inevitably, without alternatives which provide 
a more practical model of Christianity, the initial euphoria of having found a space in which to grow recedes quickly, as it becomes evident that this particular vision is impossible given the constraints of daily living.

\section{Finding friends and dancing on the edge}

The author is now increasingly aware of her context, that her attempts to model a solitary life are problematical. She is unable to make space for the contemplative life, and disillusionment begins to creep in. Contemplation, it seems, is for the few, and life is too busy. She realises that her gender may be part of both the problem and the solution.

The historical meta-narratives were constructed a world in which everything had its order (including the hierarchically structured Church), but there are inevitable casualties in that system: marginalised voices such as the poor, women, LGBTQ, Black-African and Asian people, as we know all too clearly now, are drowned out in favour of these narratives. The author too, belongs to one of those marginalised groups, ${ }^{10}$ only ticking some of the boxes of the white, Western, solitary male norm. And therein lies the problem: the possibilities and opportunities that open up in the form of Merton's solitude and Jamieson's alternative churches have their roots in the old meta-narratives which favoured the norm. So, as we splash around in the shallows, the sea floor is littered with debris from the effects of marginalisation.

The past has a place, but a dawning awareness of gender-roles means reconfiguring understanding by taking into account new narratives. Owning gender is an important aspect of realignment for women emerging from patriarchal Christian meta-narratives. While the early second-wave Christian feminists, in the 1970s and 80s, ${ }^{11}$ undoubtedly paved the way for gendered dialogue, they did little to address the norms of everyday living for women whose lives revolved around care, nurture, family and home.

A possible model which accepts the role of women as carers and extends it to encompass both female and male caring as an act of moral reciprocity,

${ }^{10}$ Albeit, the author acknowledges, a privileged one with access to medical care, education, and equal rights in the public arena.

${ }^{11}$ Mary Daly, Rosemary Radford-Ruether, Elizabeth Schussler-Fiorenza and Carol Christ are among the early Christian voices who sought to advocate women's voices in the Christian narrative. 
is that of Nel Noddings: she rejects the idea of a universal ethical judgement, and focuses instead on the 'uniqueness of human encounters'. As so much depends on the subjective experience of ethical encounters, conditions are rarely 'sufficiently similar for me to declare that you must do what I must do' (Noddings, 2003, p. 5). She posits a different form of universally accessible morality - 'the caring attitude, that attitude which expresses our earliest memories of being cared for and our growing store of memories of both caring and being cared for' (ibidem) - and proposes that we are mutually dependent even when striving for 'personal goodness':

How good $I$ can be is partly a function of how you - the other - receive and respond to me. Whatever virtue I exercise is completed, fulfilled, in you... An important difference between an ethic of caring and other ethics that give subjectivity its proper place is its foundation in relation. The philosopher who begins with a supremely free consciousness - an aloneness and emptiness at the heart of existence - identifies anguish as a basic human affect. But our view, rooted as it is in relation, identifies joy as a basic human affect ... it is the recognition of and longing for relatedness that form the foundation of our ethic. (ibidem, p. 6)

Noddings' ethics of caring and relatedness bridges the divide between Merton's approach to love, care and compassion through solitude and contemplation, and the 'Marthaesque' approach through service, busyness and doing. ${ }^{12}$ In defending caring, she identifies the problem of the male norm in institutional churches, and offers a space to explore a less hierarchical and isolationist approach to community:

If it is the case that females have easier and more direct access to caring through biologically facilitated factors, this does not imply that males have no access, but it might help to explain why men intellectualise, abstract and institutionalise that which women treat directly and concretely. It might also explain why organised religions are so often created and dominated by men. The longing for that which is not quite within reach is deep and constant. (ibidem, p. 130)

12 Luke Chapter 10: Martha's busyness in preparation for welcoming Jesus is contrasted unfavourably with the stillness and contemplative nature of the attentive Mary, who is seen as the ideal woman. This mirrors the solitudinous, contemplative approach to spiritual fulfilment of writers like Merton, who actively choose 'the better way'. For a fuller explanation, see Barbara E. Reid (1996). 
Her resolution that 'human love, human caring, will be quite enough on which to found an ethic' is centred in the awareness that this form of caring is not 'a form of agapism', and there is 'no command to love nor, indeed, any God to make the commandment' (ibidem, pp. 28-29). Noddings' rejection of the external, commanding 'male' God of Christianity, however, leaves this particular exile with the challenge of resolving fragments of faith with a new awareness grounded in feminine ethics of caring. Her approach is limited to caring for the intimate other; and, as Eileen Sowerby (2019) notes, this fails to address relations with the 'non-intimate' - an aspect which will be of significance for REs forming new communities of care. Nevertheless, this is a useful starting point for exiles to consider their own approaches to post-EPC faith. To span the divide between the commanding God and human caring as being sufficient to itself, another voice is needed.

In 1968, Dorothee Soelle published Phantasie und Gehorsam, ${ }^{13}$ which questioned the role of obedience in both national and religious life. Her experience of the blind obedience of 'idealistic or stupid young Nazis', which led them to commit 'the greatest crime in the history of my people' (1995, p. $\mathrm{x})$, caused Soelle to question historical models of Christian obedience, and to suggest instead a 'creative disobedience' situated in the figure and context of the earthly Jesus. For Soelle (1995, pp. xvii-xviii), male theological language 'is insensitive to what people experience', and 'has no appeal to change the world'. The God-image as 'father, begetter, ruler and manager of history' left her as a woman feeling incomplete in a powerful patriarchal society, so she created a new theological language of inclusivity and communality rather than power and domination. The male authority model reinforces the EPC ideal which subjugates the question 'why?'. Soelle notes that:

When obedience concentrates itself completely on a higher and guiding 'other', it becomes blind, that is, blind to the world. It hears the voice of its master in a very narrow and exclusive sense but it sees nothing. It accomplishes the act of obedience for its own sake, recognising no additional significance... An obedience that is blind to objective concerns and to the world, that merely listens to what it is told, has divested itself of all responsibility for what is commanded. Obedience and not what is to be done is the sole motivation. (ibidem, p. 16)

${ }^{13}$ Originally published in English as Beyond Mere Obedience, later changed to Creative Disobedience (1995). 
Soelle does not see belief as an ideology unconnected to real life, that has ossified into a tradition. Blind obedience is not the action of belief, but the obstruction of it and of the domain of oppression. In excising the traditional theologies of obedience ${ }^{14}$ she embraces REs, offering a new form of obedience - not 'the carrying out of commands intended to maintain ... an unchangeable order' (ibidem, p. 27), but obedience to the self, rooted in fulfilment; a concept she coins as 'phantasy':

The self-evident 'right to enjoy the earthly life' for all human beings, lies on a different level of thought, a level attested to in the Bible, but suppressed in the tradition of the church. In the Bible the world is viewed as being changeable and the possibilities for fulfilment thus provided cannot be limited by the unforeseen envy of the gods... Liberated humans are builders of well-being, they are in control of all the possibilities at their disposal and not only experience but also create it. (ibidem, pp. 46-47)

Soelle offers REs a 'thinking' approach to Christianity, freed from the old norms of authority and obedience, and advocating life on the boundaries, a space to explore both the old world and the potentials of a new one. Her insistence that we can learn from Christ is not based on his blind obedience to a powerful omnipotent God, but rather because Jesus of Nazareth is 'of all the humans who ever lived ... the person most conscious of his own identity. And ... the strength of his phantasy [fulfilment] must be understood as rising out of his joyous self-realisation' (ibidem, p. 56). Here is the possibility of personal fulfilment in social action, grounded in Jesus of the Gospels.

Notwithstanding the fact that Soelle is rather one-dimensional in her critique of patriarchal power as 'obedience to an omnipotent tyrant and to the male hierarchs who interpret his laws' (Orens, 2002), her deconstruction of ecclesial power opens up possibilities for new communities of faith grounded in human self-actualisation. To believe in Jesus Christ and the Holy Spirit does not mean submitting to patriarchal dominance; rather, in the biblical sense, a sharing of diverse people - those with whom we agree and disagree, whom we like and dislike, and who are at the edges of community:

${ }^{14}$ Most notably Baumgarten (1706-57), who writes that 'most assuredly the time will return when obedience - that is, the submission to authority, full compliance without questioning motives, the simple telling and presenting of holy things rather than the endless asking and answering of questions - will freely be acknowledged and practised as the basis of all religious training.' 
Jesus ... ate with those who were on the margins of society: cheats and prostitutes, toll collectors, all members of 'disreputable professions'. He ate with those who 'followed' him: men, women and children. He accepted invitations to meals in the homes of Pharisees precisely because on some individual questions relating to the required loyalty to Torah he thought differently from many Pharisees. There were discussions and friendly disputes at the meals... (Soelle \& Schotroff, 2002, p. 82)

The recognition that "life is more complex than the logic of clear distinctions and abstract concepts can comprehend' leads me to a more 'dialectical and multileveled approach to life' (Soelle, 1995, p. 183); thus, Soelle offers a space to breathe and permission to converse with the dissidents, the non-patriarchal voices who sit at the edges.

I was, and had been all along (to misquote Stevie Smith), not drowning but waving; the certainty of early childhood had given way to dissident voices which allowed me to find a multiplicity of meaning, and have begun to shape a new congruity and understanding.

\section{Alone Together}

The author says 'I'. I have introduced you to some of the voices which have confronted me in my exile. I have complied, agreed, doubted and challenged. My dialogues with spiritual leaders and dissenters were initially overwhelming and all-consuming, then gradually made way for a more reflective approach to Christianity. I have approached them, often at first exclusively, hoping to find that their solutions and propositions are the answers to my questions; and later on, as significant voices in the forum of my own inner dialogue.

At each point I find that I have known Christianity for the first time. Holloway's proposition that to understand Christianity is to 'dance on the edge', gave permission for rebellion against a Creed which seemed to assume a supernatural ideology. Merton's approach to the Creeds not as ends but the means to truth allowed me to deconstruct old ideologies and seek new ones to take their place. Noddings showed me my feminine voice, which spoke of caring and compassion, and gave consent to my deeper self to challenge the patriarchal Creeds. Soelle's radical social doctrine and refusal to be tied down to traditional authoritarian norms afforded the courage to learn to be who 'I am'. But all these people are only partial constructs of the self I am 
becoming; I have been given a new imagination with which to reconfigure faith. As Fowler (1995, p. 198) observes:

New strength ... comes in the rise of the ironic imagination - a capacity to see and be in one's or one's group's most powerful meanings while simultaneously recognising that they are relative, partial and inevitably distorting apprehensions of transcendent reality.

I have wrestled throughout with the problem of how to refer to myself in the singular third person as 'the author', the first person 'I', or as part of a communal 'we' in acknowledgement of others who share my exile. This dilemma also permeates my interface with the Church - one to which I have found a partial answer, in developing an independent identity within the Church which discourses with diverse Christian voices, while I explore this new space. The old Creeds now have fresh meanings and cannot be returned to their old forms. My complete self is made up of partial others and their contributions, and it will continue to be informed, guided and challenged by them. My early place of certainty has become a place of doubt and contingency; though not one of anxiety and alienation - rather, a profound doubt embedded in a deep core of human knowing. Like Eliot, I constantly return to my own Little Gidding, and find it curiously the same yet different: what possibilities arise when at each stage of all our exploring we continually 'arrive where we started / And know the place for the first time'! I invite you to do the same.

I hope this exploration has provided a starting point for discussions, whether in academia, the Church, or beyond those boundaries, which will enable us to explore diverse 'Christian' voices as part of the faith dialogue something we must surely do if institutional religion beyond the boundaries of the EPC movements is to survive in any meaningful form into the $21^{\text {st }}$ century.

I am alone and I am in community: this paradox allows for a 'Christian' life beyond the boundaries of, yet in dialogue with, institutional religion, and it allows me to both accept and reinterpret the Creeds. I leave the last word to Dorothee Soelle, whose poem 'Credo' (1975) adopts an alternative vision:

I believe...

In the possibility of a meaningful life

For all people 
I believe this world of god's

Has a future.

\section{References}

Asher, K. G. (1995). T. S. Eliot and Ideology. Cambridge: Cambridge University Press.

Bochen, C. M. (2000). Thomas Merton: Essential Writings. Maryknoll, New York: Orbis Books.

Brueggemann, W. (1993). Texts Under Negotiation: the Bible and Postmodern Imagination. Minneapolis: fortress Press.

Coyle, A. (2011). Critical Responses to Faith Development Theory: A Useful Agenda for Change?. http://epubs.surrey.ac.uk/25591/2/Faith\%20Development $\% 20$ Theory\%20complete\%20article.pdf [accessed 29.03.19].

Eliot, T. S. (1963). Collected Poems (1909-1962). London: Faber \& Faber Ltd.

Erikson, E. (1980). Identity and the Life Cycle. New York and London: W.W. Norton \& Company.

Fowler, J. W. ([1976] 1995). Stages of Faith: The psychology of human development and the quest from meaning. New York: HarperSanFrancisco.

Fowler, J. W. (2000). Becoming Adult Becoming Christian: Adult Development and Christian Faith. San-Francisco: Jossey Bass.

Fowler, J. (2004). Faith Development at 30: Naming the challenges of faith in a new millennium. Religious Education, 99(4), 405-421.

Fowler, J. W. \& Dell, M. L. (2006). Stages of Faith from Infancy Through Adolescence: Reflections on Three Decades of Faith Development Theory. In E. C. Roehlkepartain, P. E. King, L. Wagner \& P. L. Benson (eds.), The Handbook of Spiritual Development in Childhood and Adolescence (pp. 34-45). Thousand Oaks, London, New Delhi: Sage Publications.

Gold, J. M. \& Rogers, J. (1995). Intimacy and Isolation: A Validation of Erikson's Theory. Journal of Humanistic Psychology, 35(1), 78-85.

Gordon, L. (2012). The Imperfect Life of T. S. Eliot. London: Hachette Digital.

Holloway, R. (1997). Dancing on the Edge: Faith in a Post-Christian Age. London: Fount.

Holloway, R. (2001). Doubts and Loves: What is Left of Christianity? Edinburgh: Canongate.

Holloway, R. (2004). Looking in the Distance: the Human Search for Meaning. Edinburgh, New York, Melbourne: Canongate. 
Holloway, R. (2012). Leaving Alexandria: A Memoir of Faith and Doubt. Edinburgh, London: Canongate.

Jamieson, A. (2002). A Churchless Faith: Faith Journeys Beyond the Churches. London: SPCK.

Jamieson, A. (2009). Churchless Faith: Trajectories of Faith Beyond the Church from Evangelical, Pentecostal and Charismatic Churches to Post-Church Groups. International Review of Mission, 92(365), 217-226.

McDargh, J. (2001). Faith Development Theory and the Postmodern Problem of Foundations. The International Journal for the Psychology of Religion, 77(3), 185-199.

Merton, T. (1961). New Seeds of Contemplation. Tunbridge Wells: Burns \& Oates.

Merton, T. (1985). The Hidden Ground of Love: The Letters of Thomas Merton on Religious experience and Social Concerns, ed. William H. Shannon. New York: Farrar, Straus \& Giroux.

Merton, T. (1994). Witness to Freedom: Letters in times of Crisis, ed. William H. Shannon. New York: Farrar, Straus \& Giroux.

Niebuhr, H. R. ([1943] 1960). Radical Monotheism and Western Culture with supplementary essays. Louisville, Kentucky: Westminster/John Knox Press.

Noddings, N. ([1984], 2003). Caring: a feminine approach to ethics and moral education. Berkeley, Los Angeles and London: University of California Press.

Orens, J. R. (2002). The Silent Cry: Mysticism and Resistance. Anglican Theological Review, 84(4), 1053-1055.

Piaget, J. (2007). The Child's Conception of the World. Plymouth, UK: Rowman \& Littlefield Publishers, Inc.

Reid, B. E. (1996). Choosing the Better Part?: Women in the Gospel of Luke. Collegeville, Minnesota: The Liturgical Press.

Slee, N. (2003). Faith and Feminism: An Introduction to Christian feminist Theology. London: Darton, Longman and Todd.

Soelle, D. ([1968] 1995). Creative Disobedience. Cleveland Ohio: The Pilgrim Press.

Soelle, D. (1975). Revolutionary Patience. Eugene, Oregon: Wipf and Stock Publishers.

Soelle, D. \& Schotroff, L. (2002). Jesus of Nazareth. London: SPCK.

Smith, S. (1958). Not Waving but Drowning. Andre Deutsch.

Sowerby, E. (2019). Nel Noddings' Caring: a critical analysis. https://www.researchgate.net/publication/29735599_Nel_Noddings\%27_Caring_a_critical_analysis [Access: 8.03.19]

Tillich, P. (1949). The Shaking of the Foundations. London: Penguin. 
